\title{
ADVANCED TEACHING METHODS FOR STUDENTS' COMPETENCIES DEVELOPMENT
}

\author{
Jekaterina Bierne \\ Jelena Titko \\ Edgars Cerkovskis
}

\author{
Anita Lasmane \\ Ekonomikas un kulturas augstskola, Latvia
}

\begin{abstract}
Competence-based approach to study process is frequently discussed topic among academicians, learners and government authorities due to its practical contribution to better graduates' employment abilities. The aim of the given study is to identify teaching methods with the biggest contribution to development of students' competencies. Bachelor level students of management-based study courses were surveyed in order to evaluate the progress in acquiring certain management competencies. Self-evaluation study was performed before and after the course. The acquired data was processed and the contribution of analysed teaching methods to competencies' development was assessed.
\end{abstract}

Keywords: competencies, management course, teaching methods.

\section{Introduction}

New skills for children and adults in the digital era, competence-based education (CBE) approach, core competencies for lifelong learning and related topics are frequently debated at the national and EU level (EC, 2016; EC, 2014), as well as a "need to improve the quality and relevance of the skills and competences" (EACEA \& Eurydice, 2012) has been recognised.

In this regard, the most important issues are identification of skills and competencies needed for better citizens' employment, as well as relevant changes in educational systems and promoted activities in learning/teaching processes (Power \& Cohen, 2005; Deißinger \& Hellwig, 2011; Elsevier Education, 2014).

The goal of the research was to identify teaching methods with the biggest contribution to development of students' competencies.

To achieve the research objectives, four-stage study was conducted by the authors: (1) list of the competencies was created by the lecturers - research participants - based on their professional experience and competencies mentioned 
in the Latvian Classification of Occupations; (2) contribution of the predetermined teaching methods to each competence development was evaluated by the lecturers; (3) and (4) bachelor level students of management-based study courses were surveyed in order to evaluate the progress in acquiring certain management competencies. Self-evaluation study was performed before and after the course.

\section{Competency-Based Approach to Study Process}

Competency-based business and management education aims to bring about the sequential acquisition of competencies required for entrepreneurship and management practices. Competitiveness of the enterprise based on its core competence, which emerges from the competencies of managers and other employees. In recent decades, society and professional associations have come to idea of increasing importance of sustained professional competence, giving rise to competency based education. CBE essential components are: measure of learning outcomes rather than seat time, students advance upon mastery, competencies that are explicit, measurable and transferable, rigorous assessment methods, and personalized learning approaches (Rasmussen et al., 2016). Competencies are the core of competency based curriculum in management and business study programs, they should be aligned with both industry and academic expectations. The process of defining competencies is one of the most important steps in the development of a CBE program, as the competencies required for a degree determine the focus of learning and assessment. Many of the newest models of competency-based education offer online formats, multiple modes of learning activities, and structures that permit students to learn and demonstrate required competencies at their own pace. (Klein-Collins, 2013). Competency based approach to study process implies explicit process of mapping competencies to courses, methods and learning outcomes (Johnstone \& Soares, 2014). Competency based education accommodates the fact that students bring diverse levels of prior experience and knowledge within subject. It implies continual analysis of each process, method and element of the study program contribution to students' progress in acquiring certain competencies.

\section{Advanced Teaching Methods in a Modern Education Process}

Competency based approach to study process shifts the emphasis towards outcomes, capabilities and learner-centeredness. Due to highly changing business environment, many authors emphasise the need to advance managerial education for all type of students using interactive and action-based teaching methods (Bock et al., 2013; Morris et al., 2013; Neck et al., 2014). Those methods are seminars, 
tutorials, workshops, games, case analysis, problem based learning and practical exercises. Seminar is a form of academical instruction, bringing together small groups of students requested to actively participate and focusing on some particular subject. Tutorial is a small class for one or a few students, more interactive and specific than lecture or seminar, giving individual attention to each participant. Workshop implies training of practical skills, and presenting individual or joint project as an assessable outcome. Problem based learning is an dynamic classroom approach focusing on exploration of real world challenges, during which students are collaborating in order to investigate and respond to a complex question or problem. Case study or analysis is a practically focused research and analysis of definite case (for business and management students usually corresponding to entrepreneurship practices), identifying its causes, influencing factors and possible solutions. Together with a focus on sustained evidence of professional competence competency based approach to study process calls for advanced methods of teaching, customizing programs to the students by offering learning activities in a range of modes, including class exercises, written materials, video lectures, workshops, tutorials, demonstrations and games (Doll, 2015; Entwistle, 2015). Research is aimed to investigate a contribution of different teaching methods to students' progress in acquiring certain management competencies.

\section{Methodology}

To achieve the research objectives, four-stage study was conducted by the authors:

1. The list of basic management competencies and course-specific competencies was developed by the lecturers of the managementrelated courses of the University College of Economics and Culture.

2. Contribution of the pre-determined teaching methods to each competence development was evaluated by the lecturers.

3. Students of the relevant courses were surveyed in order to evaluate the level of each specific competence before the course.

4. Students of the relevant courses were surveyed in order to evaluate the level of each specific competence after the course.

Study participants (lecturers and students) represented three management courses: (1) Strategic management, (2) Quality management, (3) Personnel management. The list of basic management competences was created though indeep discussion within the authors' group, based on the information provided in the Latvian Classification of Occupations. Specific competences were identified by the lecturers, based on their professional experience and course specifics. 
Jekaterina Bierne, Jelena Titko, Edgars Cerkovskis, Anita Lasmane. Advanced Teaching Methods for Students' Competencies Development

The list of basic competencies is presented in the Table 1. Competencies were identified not only for a company's, but also for business unit managers.

Table 1 Basic competencies for managers

\begin{tabular}{|l|l|}
\hline \multicolumn{1}{|c|}{ Basic competencies } & \multicolumn{1}{|c|}{ Label } \\
\hline $\begin{array}{l}\text { Ability to determine and formulate mission and goals of a company; to } \\
\text { develop a strategic plan }\end{array}$ & Strategic goal \\
\hline $\begin{array}{l}\text { Ability to analyze, systemize and integrate the internal and external } \\
\text { information for a company's need }\end{array}$ & Information \\
\hline $\begin{array}{l}\text { Ability to plan, manage and coordinate the activity of a company as a } \\
\text { whole }\end{array}$ & Management \\
\hline Ability to determine performance measures aligned with strategic goals & $\begin{array}{l}\text { Performance } \\
\text { measures }\end{array}$ \\
\hline $\begin{array}{l}\text { Ability to evaluate business performance, identify problems and find } \\
\text { solutions }\end{array}$ & $\begin{array}{l}\text { Performance } \\
\text { evaluation, } \\
\text { problem } \\
\text { solving }\end{array}$ \\
\hline Ability to work in team, to delegate duties. Leadership competencies & Leadership \\
\hline Ability to work individually, to take responsibility for results of own work & Individual work \\
\hline Ability to report about company's performance & $\begin{array}{l}\text { Presentation } \\
\text { competence }\end{array}$ \\
\hline Ability to apply information technologies & IT competence \\
\hline
\end{tabular}

The contribution of eight teaching methods to students' competencies development was analyzed within the current study: (1) seminar, (2) tutorial, (3) exercise classes, (4) workshop, (5) case study, (6) problem-based learning (PBL), (7) distance learning, (8) gamification.

The lecturers were offered to mark the certain method in relationship with the certain competence, if, on their opinion, this method contributes to the competence development.

Specific competencies for individual courses are presented in the Results section. The students of relevant courses were offered to perform self-evaluation regarding each competence, using 5-point scale ( 1 - competence is absolutely not developed; 5 - competence is highly developed). Iteration of the survey before and after the course was made in order to evaluate the progress in competencies development that, in turn, indirectly allowed making conclusions about teaching quality.

\section{Results}

The lecturers participated in the survey evaluated each of the analyzed teaching methods in terms of their application possibility to development of 
certain management competencies. The results of the second stage of the survey are summarised in the Table 2.

Table 2 Lecturers' viewpoint about teaching methods' contribution to competencies development

\begin{tabular}{|l|l|l|c|}
\hline \multicolumn{1}{|c|}{ Basic competencies } & \multicolumn{1}{|c|}{$\begin{array}{c}\text { Methods marked by } \\
\text { lecturers as contributors }\end{array}$} & \multicolumn{1}{|c|}{$\begin{array}{c}\text { Teaching } \\
\text { method }\end{array}$} & $\begin{array}{c}\text { Frequency of } \\
\text { selection of the } \\
\text { method }\end{array}$ \\
\hline Strategic goal & $\begin{array}{l}\text { Seminar; Exercise classes; } \\
\text { Workshop; Case study }\end{array}$ & Seminar & 7 \\
\hline Information & Tutorial; Case study; PBL & Tutorial & 5 \\
\hline Management & Seminar; Workshop; PBL & $\begin{array}{l}\text { Exercise } \\
\text { classes }\end{array}$ & 4 \\
\hline Performance measures & $\begin{array}{l}\text { Tutorial; Case study; PBL; } \\
\text { Distance learning; Exercise } \\
\text { classes }\end{array}$ & Workshop & 8 \\
\hline $\begin{array}{l}\text { Performance } \\
\text { evaluation, problem } \\
\text { solving }\end{array}$ & $\begin{array}{l}\text { Case study; PBL } \\
\text { Leadership }\end{array}$ & $\begin{array}{l}\text { Seminar; Workshop; Case } \\
\text { study; Gamification }\end{array}$ & PBL \\
\hline Individual work & $\begin{array}{l}\text { Seminar; Tutorial; Exercise } \\
\text { classes; Workshop; Distance } \\
\text { learning; Gamification; }\end{array}$ & $\begin{array}{l}\text { Distance } \\
\text { learning }\end{array}$ & 7 \\
\hline $\begin{array}{l}\text { Presentation } \\
\text { competence }\end{array}$ & Workshop & Gamification & 5 \\
\hline IT competence & $\begin{array}{l}\text { Seminar; Workshop; Distance } \\
\text { learning }\end{array}$ & & 4 \\
\hline
\end{tabular}

All participating lecturers shared their opinion about workshop as the only method contributing to development of students' presentation skills. Besides, on the viewpoint of study participants, the competence "performance evaluation, problem solving" can be developed, using the methods "case study" and "problem-based learning". However, regarding other competencies lecturers ideas and opinions are divided. The frequency of leading selected methods may reflect the fact of merging of different methods within teaching practice. As a result kind of joint interactive group work method is emerging, including 1) recurrent students' group meeting with a particular focus (element of seminar), 2) during which students are investigating and analysing definite real world problem (PBL element), 3) which is, typically, a particular case of problematic business or managerial practice (case analysis element) 4) and implying elaboration of kind of solution, project, scenario or strategy in order to respond to studied challenge (workshop element). 
Figure 1 reflects the results of students' self-evaluation study before and after the study course.

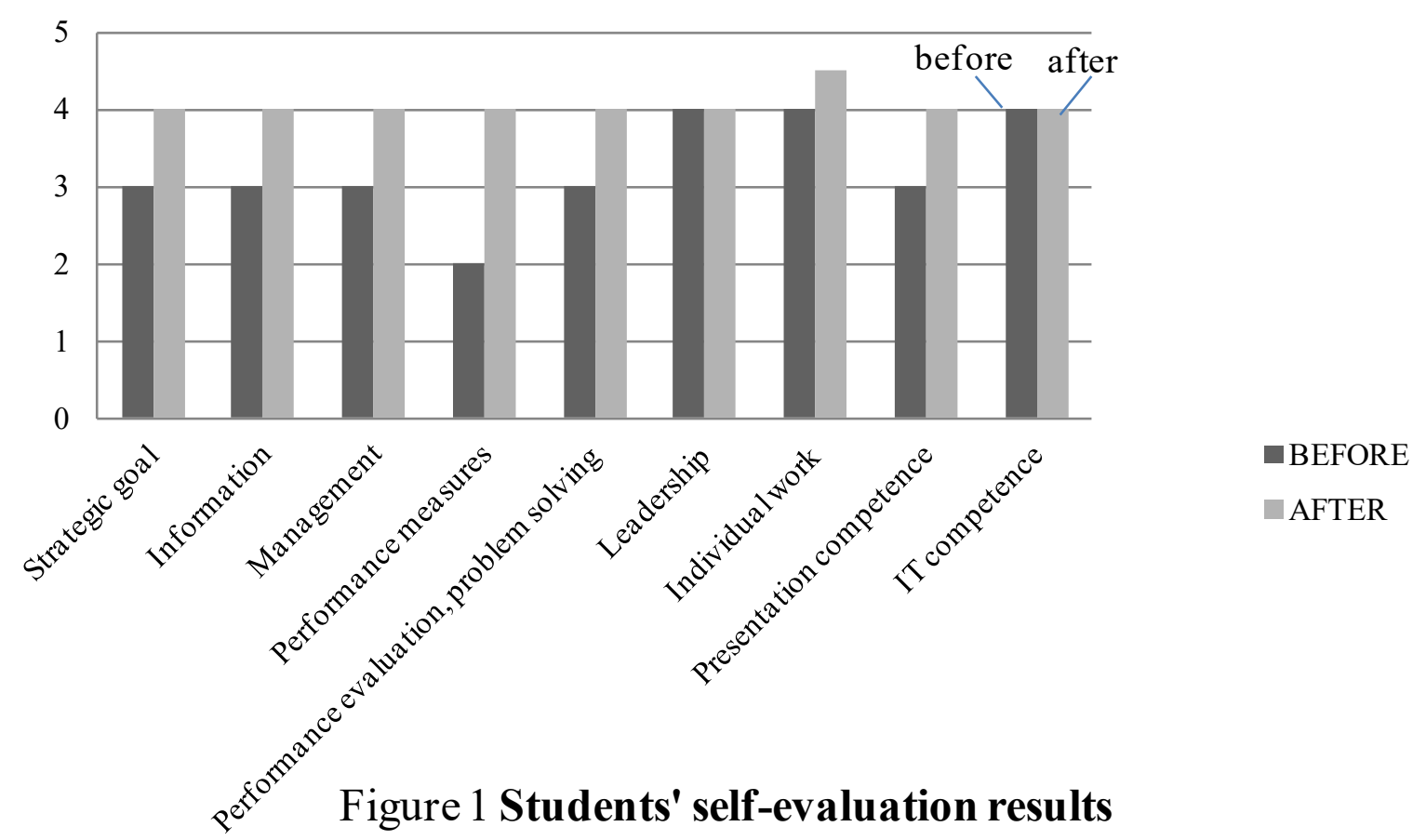

According to the results received before the course, the worse developed competence of the students was "Ability to determine performance measures aligned with strategic goals" (label "Performance measures"). In turn, the highest level of development was assigned to the competencies "Ability to work in team, to delegate duties. Leadership competencies" (label "Leadership") and "Ability to work individually, to take responsibility for results of own work" (label "Individual work"). After the course the least changed ratings are "Leadership competency", "Individual work competency" and "IT competency", which get the highest self-evaluation results prior to the course. Taking into account teachers' emphasis on such teaching methods as seminar, workshop, cases and PBL, related to group work, collaboration and joint contribution to the outcome, it is clear why students are not associating such practices with leadership or individual work competencies. The progress, however, relates to acquiring such management competencies as "Ability to determine performance measures aligned with strategic goals" (label "Performance measures"), "Ability to analyze, systemize and integrate the internal and external information for a company's need" (label "Information") and "Ability to determine and formulate mission and goals of a company; to develop a strategic plan" (label "Strategic goal"), "Ability to evaluate business performance, identify problems and find solutions" (label "Performance 
evaluation") and "Ability to report about company's performance" (label "Presentation competence"). These data corresponds with nature of selected teaching methods, merging into joint teaching practice, emphasizing group work. This practice includes analyzing internal and external information for the needs of certain organizational cases, identifying causes of problems and modeling possible response to organizational challenge, as well as presenting the results and elaborated solution, based on definite measurable criteria. All mentioned elements are corresponding to competences, in which students reported progress after course.

Regarding specific management competencies, there were identified 21 competencies in total for three management courses. The list included such competencies, as "Ability to properly use professional terminology", "Ability to organize team-working, develop communication, promote corporate identity", "Ability to analyze market trends; Ability to develop staff training plan/ system", "Ability to link personnel management efficiency and company's strategy" and others. Seminar was selected an appropriate method to development of 9 competencies. The results for other teaching methods are, as follows: tutorial -9 ; exercise classes - 6; workshop - 10; case study - 8; PBL - 7; Distance learning 1; Gamification - 9. Low rate of distance learning shows that working within blended learning students' groups teachers are focusing on classroom activities.

Figure 2 represents the results of students' survey - self-evaluation of specific competencies. Since the competencies identified by lecturers were absolutely different, the authors focused on the evaluation of progress.

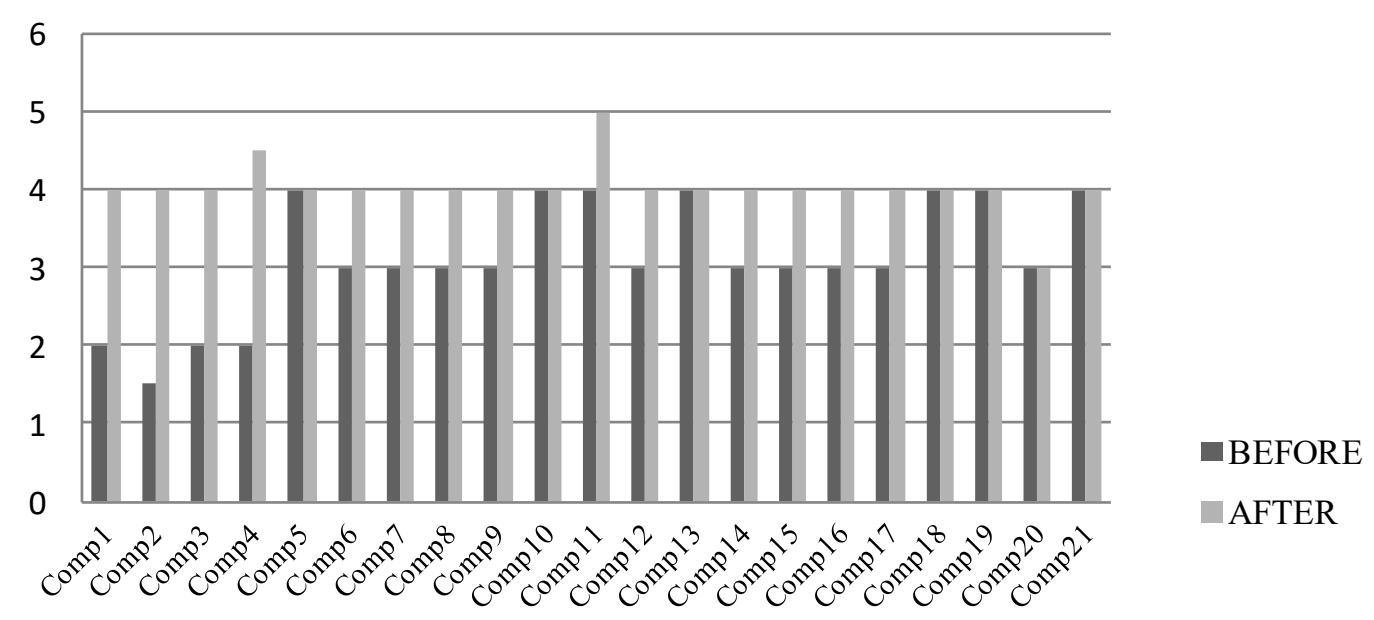

Figure 2 Evaluation of specific competencies by students: before and after the course 
From the Figure 2 it is obvious that the students increased certain competencies significantly during the study course. This is especially relevant for those competencies which were evaluated as less developed before the course: ability to optimize planning and organizing processes within enterprise (comp 1), ability to analyze and to optimize motivating and control systems within a firm (comp 2), ability to understand and to promote appropriate organizational culture and corporate identity (comp 3), and ability to use correctly professional terminology of strategic management (comp 4). No progress marked in those competencies which were relatively highly evaluated prior the course: ability to define personnel competencies and duties in order to ensure production quality (comp 5), ability to indentify production quality impacting risks and factors (comp 10), ability to manage group work and information channels at the enterprise (comp 11), ability to identify HRM goals and direction (comp 13), ability to work in psychological tension circumstances and to solve problems (comp 18), ability to make HRM related decisions (comp 19), ability to think creatively (comp 21). Relative progress were notices by students in acquiring such competencies as: ability to manage quality control procedures (comp 6), ability to manage innovations (comp 7), ability to conduct costs analysis (comp 8), ability to analyze labour market trends (comp 12), ability to match certain HRM functions such as selection, assessment etc. With organizational strategy (comp 15), ability to create personnel learning system within enterprise (comp 17). Analysis of those data is relatively complicated due to the variety and specifics of mentioned competencies. Some of them are more narrow, instrumental and specified then another. The more critical is students self evaluation by certain competence before the course, the more likely progress will be reported after the course. This tendency may show, that teachers chosen teaching methods are helping students to experience progress in acquiring the underdeveloped competencies within competency based study approach.

\section{Conclusions}

1. Due to the fact, that there are multiple potential linkages between learning activities, teaching methods, learning outcomes and competencies within CBE framework, it's hard to make credible causal claims under conditions of complexity. Still it is possible examining certain advanced teaching methods' contribution to progress into acquiring certain competencies through self-evaluation of teaching and learning process participants.

2. Based on study results (Table 2), teachers repeatedly selected methods forms kind of clusters, emphasizing joint interactive group work, including elements of seminar (recurrent students' group meeting with a particular focus), element of problem based learning (investigating and analysing 
definite real world problem), case analysis element (typically, a particular case of problematic business or managerial practice) and workshop element (elaboration of kind of solution, project, scenario or strategy in order to respond to studied challenge). Within such approach the least changed rating have such competences as leadership, individual work and IT competencies.

3. According to the students' survey results (Figure 1, Figure 2), the most progressing competences from the students' viewpoint are "Ability to determine performance measures aligned with strategic goals", "Ability to analyze, systemize and integrate the internal and external information for a company's need", "Ability to determine and formulate mission and goals of a company; to develop a strategic plan" and "Ability to evaluate business performance, identify problems and find solutions".

4. Least progressing competencies were "Leadership" and "IT competence", however, these competencies are possible to be developed at the work place or within professional training programmes, not in the class.

\section{References}

Barbezat, D. P., \& Bush, M. (2013). Contemplative practices in higher education: Powerful methods to transform teaching and learning. John Wiley \& Sons.

Bok, H. G., Teunissen, P. W., Favier, R. P., Rietbroek, N. J., Theyse, L. F., Brommer, H., ... \& Jaarsma, D. A. (2013). Programmatic assessment of competency-based workplace learning: when theory meets practice. BMC medical education, 13 (1), 123.

Competency-Based Education: Achieving superior outcomes through flexible, personalized learning (2014). Elsevier Education. Downloaded from https://evolve.elsevier.com/ education/pdf/CBE_Trend_Perspective_2014.pdf

Deißinger, Th., \& Hellwig, S. (2011). Structures and functions of Competency-based Education and Training (CBET): a comparative perspective Mannheim: Federal Ministry of Economic Cooperation and Development.

Doll Jr, W. E. (2015). A post-modern perspective on curriculum. Teachers College Press.

EACEA, Eurydice. (2012). Developing Key Competencies at School in Europe: Challenges and Opportunities for Policy. Eurydice Report. Downloaded from http://eacea.ec.europa.eu/education/eurydice/documents/thematic_reports/145en.pdf

Entwistle, N. (Ed.). (2015). Handbook of Educational Ideas and Practices (Routledge Revivals). Routledge.

European Commission. (2015). European Semester Thematic Fiche: Skills for the Labour Market. Downloaded from http://ec.europa.eu/europe2020/pdf/themes/2015/ skills_for_labour_market_20151126.pdf

European Commission. (2016). A New Skills Agenda for Europe: Working together to strengthen human capital, employability and competitiveness. Downloaded from https://ec.europa.eu/transparency/regdoc/rep/1/2016/EN/1-2016-381-EN-F1-1.PDF

Johnstone, S. M., \& Soares, L. (2014). Principles for developing competency-based education programs. Change: The Magazine of Higher Learning, 46 (2), 12-19.

Klein-Collins, R. (2013). Sharpening our focus on learning: The rise of competency-based approaches to degree completion. Occasional Paper, 20. 
Jekaterina Bierne, Jelena Titko, Edgars Cerkovskis, Anita Lasmane. Advanced Teaching Methods for Students' Competencies Development

Morris, M. H., Webb, J. W., Fu, J., \& Singhal, S. (2013). A Competency-Based Perspective on Entrepreneurship Education: Conceptual and Empirical Insights. Journal of Small Business Management, 51 (3), 352-369.

Neck, H. M., Greene, P. G., \& Brush, C. G. (Eds.). (2014). Teaching entrepreneurship: A practice-based approach. Edward Elgar Publishing.

Power, L., \& Cohen, J. (2005). Competency-Based Education and Training Delivery: Status, Analysis and Recommendations. Downloaded from http://datatopics.worldbank.org/hnp/ files/edstats/IDNdprep05.pdf

Rasmussen, K., Northrup, P., \& Colson, R. (2016). Handbook of Research on CompetencyBased Education in University Settings. IGI Global, 454 p. 